$\xi=-1$

\title{
Social Engineering for Ethical Dilemma about Anti-Corruption Intellectual Consciousness
}

\author{
Arie Wahyu Prananta ${ }^{1 *}$, Hotman Siahaan ${ }^{2}$ \\ ${ }^{1}$ Doctorate Program Student, Faculty of Social and Political Science, Indonesia, Universitas Airlangga \\ ${ }^{2}$ Faculty of Social and Political Science, Indonesia, Universitas Airlangga \\ *Corresponding author E-mail: arie.wahyu-13@fisip.unair.ac.id
}

\begin{abstract}
This study aims to find that high integrity is to break away from personal roles and public roles, starting with the selection of places they develop intellectuals in the anti-corruption movement. So they choose a place that can accommodate the minds of those who are antimainstream and dare to get out of their comfort zones and enter into a system to change the system, even though at risk they will become isolated individuals, unpopular and always in a separate space. For those who from the beginning chose the area of power and politics gave rise to two groups of intellectuals, namely the group that still wishes to carry out anti-corruption thinking and groups that merge into corruptors. The ethical dilemma for groups in the area of the anti-corruption movement is lighter because the ethical dilemma is in his role. While the groups in the field of power and politics are more massive because some can only see and experience extraordinary shock until stressed but cannot report it, some others fall into the world of corruption.
\end{abstract}

Keywords: Intellectual consciousness, corruption, phenomenology, interpretive, social engineering.

\section{Introduction}

The form of the relationship between the government, intellectual figures, and society in the life of the nation and state has long existed. The linkage of the link in question is in the awareness of the very central role of intellectuals [1]. Intellectual consciousness roles are meant more by the position that is owned as a change agent in developing the country, with brilliant ideas, which can be beneficial to society. While on the other hand, it can also be a source of problems and damage. Intellectual sociology reveals that in society, intellectuals are always faced with an ethical dilemma of choices that favor power, are conservative and allergic to change, choose a position to be ever critical and autonomous and independent of the government [2].

Human knowledge is ambiguous. Thus it is said because both types of expertise namely pre-knowledge (implicit and blurred, but tremendous and exhaustive) and experience (which are bright, but limited) that are never separated are implicit and explicit, absolute and relative and divine and human never separated one another [3].

Some research in the field of ethics uses moral development theory to observe the basis of individuals doing an action. One of the most frequently used approaches is the level of Kohlberg's moral reasoning. Knowing the level of one's moral argument will be the basis for recognizing the tendency of individuals to perform specific actions, especially those related to ethical dilemmas, based on the level of moral argument [4]. Individual ability in completing ethical dilemmas is influenced by the level of moral argument [5]. The higher the level of moral reasoning of individuals, the more likely they will not cheat [6]. The higher the moral standard of individuals will be more sensitive to ethical issues [5]. Of all the previous studies, it seems only to see the role of intellectuals from the perspective of characters when intellectuals enter the system and intellectuals tend to change and choose to become a corruptor when dealing with the system or even become the leading actor of corruptors. These studies have not been able to swoop sharply to see why intellectual groups can experience change or more specifically why intellectual consciousness is changing. This is where the position of this study is significant to fill the space or gap to see an consciousness in the dilemma role of intellectual groups.

\section{Intellectual Idealism}

The debate over ethical dilemmas in a discourse triggers a tension and choice between elitism and egalitarianism in the role of an intellectual. In social reality, this discourse always encounters a conflict in the ethical dilemma between the theory found and its practice. This difference raises the ethical battle. Intellectuals struggle to break the ethical struggle, especially in Asia (east) the intellectuals themselves become more political elites than independent intellectuals, this is where we see intellectuals in the east (ASIA) facing the battle of ethical dilemmas between objective idealism or entering into elitism the ruling regime [1].

Many studies show that Corruption and Trust and democracy have a lot of intellectuals who are the main actors behind several corruption cases including in Italy, Russia, Europe, America and Asia [7]-[11].

Some types of intellectuals in Indonesia, among others, there are five classes of intellectuals. (1) The quality of intellectuals who have an awareness of expressing honesty and truth in opinion despite dealing with death. (2) The type of intellectuals is a group that has an appreciation in communicating truth and honesty but do not dare to deal with death when forced not to acknowledge the fact this group wants to admit untruth, even though behind moves and whispers against unrighteousness. (3) The class of 
intellectuals who have a current-minded consciousness such as fighting against immorality and honesty but have no desire and ambition to change things and remain neutral. (4) Intellectual groups who often do troubles and riots and express ideas that very critical of the authorities even though this class of intellectuals feels uncomfortable or uncomfortable with the local authorities, but when given power and position to be rulers who are "fat and bald" are subject to the incumbent. (5) This class of intellectuals cannot think logically and critically in uncovering untruth and are unable to spearhead changes in the fight against unrighteousness, as in the expression of groups which are called intellectual groups "where suits and ties wave in the wind, that's where the intellectuals anchored " [12].

A study in ASIA which covers developing countries of Indonesia, the Philippines, and Thailand. It stated that intellectuals in Indonesia, departing from the revival of the intellectual role of the anticorruption movement in the post-reform movement, after postreform in 1998, there were dramatic changes in many fields of social life in Indonesia. Post-reformation strengthening the public position (the intellectual movement) has a large enough pore and becomes a balancing force in the growth of a country's democratic process [13]. The emergence of new intellectuals is expected to bring about a form of change agent. Meanwhile corruption, collusion, and nepotism continue to be prominent, but in practice, they become decentralized or multicentered after reform [13], [14].

Intellectual characteristics include: First, Having knowledge and knowledge of religion that is able to be theorized and realized in the community; Second, can speak the language of his people and be able to adapt to the environment; and Third, having a social responsibility to transform a static society into a dynamic one [2] Among those included in this intellectual element are academics on campus.

Then in a study that analyzed that the authoritarianism of the New Order political system also did not kill the activities of civil society organizations [15], [16]. The new order political system gave birth to its enemies who worked outside the system because the system has become synonymous with the state itself [17]. Although under pressure from power, the civil society movement (the Intellectuals) in this era continued to play its role. If it may be said, it is a counterweight to the power of the state in several ways, such as providing an alternative view on policy. Democracy in the post-reform period triggered the growing involvement of civil society roles. The civil society movement especially the intellectuals in the new order era led to the overthrow of the government of President Soekarno (old order). In 1998 in the New Order era [17].

Intellectuals who are actors inside or outside the government are the embodiment of civil society that cares about efforts to eradicate corruption to complete the reform agenda in Indonesia [18]. The guardian of democracy enforcement is the Intellectual, where the Intellectual group always guard the democratic process to run dynamically and full of vitality and achieve its goals [19].

The urgency of strengthening the role of intellectuals as one of the motors in strengthening civil society is increasingly prominent when a less powerful and corrupt country also requires its people not to be quiet and stand by but to work to fill the empty spaces left by the government. The question is how the role of intellectuals in building an awareness movement of the anti-corruption movement, by holding the profession's ethical dilemma when faced with the anti-corruption movement. Understanding the dilemma in an ethic provides the best and correct choice in some of the best and right choices. The key word is that individuals in providing the best and most correct choices must be committed in a critical awareness [20].

Of the many corruption cases in Indonesia, Indonesia seems to be a country that is included in the criteria for emergency corruption, because the corruption crime itself is covered in Extraordinary Crime which requires delicate handling. According to "Bambang Widjayanto," the former chairman of the KPK revealed that indicating metamorphosed corruption in the form of a systematic crime is parallel and very severe with narcotics crime in Indonesia as revealed in the Cultural speech held by Transparency Indonesia [21], [22]. The fact that corruption in Indonesia is very severe is: (1) the fact that the poverty rate from corruption has increased from 2014 to 30.25 previously in 2013 to 28.28 . (2) the Indonesian archipelago numbered 17,504 islands supported by maritime natural resources, the emergence of lanes - mouse trails outside ports outside the official seaports exacerbate the level of corruption in Indonesia. (3) area number 3 in the world about the richness of forestry resources (timber) and mangrove forests cleared due to illegal logging. (4) Meeting liberalization, democratization and decentralization in "political economy rents" makes a long list of corruption in the Ministry of Religion (Hajj Program) and Ministry of Health (BPJS) needs to be increased public accountability in reducing corruption massivity. (5) Oligarchy in the reform era after the New Order era precisely created a black conglomerate cartel [21], [22].

\section{Connection Of Idealism And Social Realty Intellectual Anti-Corruption}

Corruption is very dangerous for human life, so it requires very systemic prevention and repression with very varied network patterns [23], [24]. This study relies on approaches to aspects of social, political, bureaucratic, economic and individual life. Eradication of corruption is formulated in the strategy of eradicating corruption, in the form of a pyramid, which at its peak is prevention (enlightenment), while on both sides of each is public education and punishment as in the southern African countries [25]-[27]. Supervision and enforcement of the Civil Society between bureaucrats, people in business and the military became a movement of awareness against corruption inherited by the new Order Regime [2].

The number of studies that use the perspective of law enforcement enforcement, and network corruption approaches as well as advocacy, all of which are paradigmatic in the political economy, this still invites criticism, because it cannot dictate sharply to provide comprehensive solutions. The role of autonomy and independence of intellectuals that seem to be ignored, mainly because it is considered in emphasizing the power of structures that limit awareness of the role of intellectuals [28].

The study of the role of intellectuals who focus on the problem of corruption with a political economy and power approach only rely on intellectual groups that are more general and cannot explain more specifically about the role of individual creative members in the institution [29], [30]. This perspective seems to ignore the aspect of awareness, the dynamic/creative side of the intellectuals themselves which allows them to act according to their independence and autonomy in the ethical dilemma. The political-economic perspective is also more inclined to look at the microstructure of a phenomenon, and ignore the detailed aspects of the phenomenon. In other words, this perspective tends to simplify the complexity of the role of intellectuals.

At this point, studies that use theoretical perspectives that can position the role of intellectuals as individuals in ethical dilemmas as creative actors who can have the power to be autonomous and independent become interesting to be appointed. Or in other words, seeing the role of intellectuals is not merely not only as a "derivative" of the economic and political power structures surrounding them. Awareness of the ethical dilemma of intellectual role seems to be a very long debate. Intellectual characters should free themselves from the passion of nationality, race, and class, or in other words, awareness of the dilemma of universal humanitarian ideas must emerge not from the contemplation of national political and strategic experts who are close to the peak of elite power, but must emerge from within himself [31]. So that it can pattern the diversity of experience about intellectual awareness in facing the pressure of the anti-corruption movement's ethical dilemma in Indone- 
sia and finding ways to build intellectual anti-corruption awareness when facing the power and political dilemma pressure.

\section{Conclusion}

This study found that there are many different experiences experienced by intellectuals, which are basically the form of diversity that starts from when the intellectuals "choose" a place to move, the first group chooses where to move in the area of activity in an anti-corruption institution, and the other group chooses location of operation in power and politics. Furthermore, the two places of activity create other forms of diversity, namely: those who are always faced with a choice which is the most correct of the best, and which should take precedence between personal interests in the family to fulfill the needs of life or the public role of working when they work in institutions anti-Corruption. Ethical dilemmas are also experienced by anti-corruption activist groups, where they are always in an isolated position in social relations in the community or even by their family members.

Regarding their ability to separate public roles and personal roles, this study found three groups. Namely (1) groups that were able to maintain their integrity well when they entered the power system and they did not commit corruption and they prevented and eradicated corruption. (2) Groups that can escape from the pressure of ethical dilemmas, in the sense that they do not commit corruption in their environment which is a robust and political environment. They are stressed to see people in their environment commit corruption. So they do not determine corruption but cannot prevent and eradicate corruption in their environment, so he is in the category of 'omitting' the perpetrators of corruption, because he is not able to fight corruption, for fear of having problems in his position in the place he its activities. (3) groups that commit corruption because of their inability to separate public roles and personal roles.

These findings, especially the second and third variants, resulted in the spread of corruption outbreaks in all aspects of life, especially intellectuals, and it is not wrong to call it "QuoVadis" for intellectual integrity. This is well founded on the growing number of intellectuals who are corruptors, arrested and convicted, and fewer and fewer intellectuals choose to follow and work on the anti-corruption movement and anti-corruption institutions. Fear of alienation, unpopularity and loneliness and despair of not being able to escape the pressure of ethical dilemmas are the reasons for theirs.

Next is about the dilemma choice and the way that the Intellectual Craftsmanship takes in building awareness of anti-corruption when facing the dilemma of power and politics. With the many diversity of experiences found in this study, there are also many dilemmatic choices and methods adopted by Intellectual Craftmanship. This study found that high integrity to break away from personal roles and public roles. Have ambitious radicals or think anti-mainstream and the courage to get out of the comfort zone and enter into a system to change the system with the risk of being an isolated person, not famous and always in the space of solitude and experiencing limitations in his personal life are some things that can raise and build awareness of anti-corruption.

Nevertheless, it should be remembered that the anti-corruption awareness movement possessed by anti-corruption intellectual groups is not merely a pure awareness formed from the individual's ethical and moral actions in the sense of growing out of his self, but in the form of a consciousness built from intersubjective experiences. Which starts from childhood. Also the period in which they study from elementary school to university. The awareness of the anti-corruption movement then developed after they entered and worked in an institution that focused on the anticorruption movement. Along with the emergence of consciousness of the anti-corruption movement that is the idealism and essence of their lives began to get space in institutions where the activists worked. Anti-corruption awareness itself is built from five things, namely: "Integrity, Commitment, Choice, Resistance, and Social piety."

\section{References}

[1] J.-W. Müller, "Julien Benda's Anti-Passionate Europe," Eur. J. Polit. Theory, vol. 5, no. 2, pp. 125-137, 2006.

[2] C. Kurzman and L. Owens, "The sociology of intellectuals," Аnnи. Rev. Sociol., vol. 28, no. 1, pp. 63-90, 2002.

[3] W. Hartanto, "KESADARAN HUKUM SEBAGAI ASPEK DASAR POLITIK HUKUM LEGISLASI: SUATU TINJAUAN FILSAFAT," J. Rechts Vinding Media Pembin. Huk. Nas., vol. 4, no. 3, pp. 469-483, 2015 .

[4] N. Puspasari and E. Suwardi, "Pengaruh Moralitas Individu Dan Pengendalian Internal Terhadap Kecenderungan Kecurangan Akuntansi: Studi Eksperimen Pada Konteks Pemerintahan Daerah,” Jurnal. Feb Ugm, Yogyakarta, vol. 1, 2012.

[5] R. E. Welton, R. M. Lagrone, and J. R. Davis, "Promoting the moral development of accounting graduate students: An instructional design and assessment," Account. Educ., vol. 3, no. 1, pp. 35-50, 1994

[6] W. WILOPO, “Analisis Faktor-faktor yang Berpengaruh Terhadap Kecenderungan Kecurangan Akuntansi: Studi pada Perusahaan Publik dan Badan Usaha Milik Negara di Indonesia," Indones. J. Account. Res., vol. 9, no. 3, 2006.

[7] V. Yadav, "Legislative institutions and corruption in developing country democracies," Comp. Polit. Stud., vol. 45, no. 8, pp. 10271058, 2012.

[8] S. Rose-Ackerman, "Corruption and the criminal law," in Forum on Crime and Society, 2002, vol. 2, no. 1, pp. 3-21.

[9] J. W. Musila, "Does democracy have a different impact on corruption in Africa?," J. African Bus., vol. 14, no. 3, pp. 162-170, 2013.

[10] S. Rose-Ackerman, "Anti-Corruption Policy: Can International Actors Play a Constructive Role?," 2011.

[11] A. Pellegata, "Constraining political corruption: an empirical analysis of the impact of democracy," Democratization, vol. 20, no. 7, pp. 1195-1218, 2013.

[12] Y. B. Mangunwijaya, Teknologi Dan Dempak Kebudayaannya. Yayasan Obor Indonesia, 1983

[13] A. Ufen, "Political party and party system institutionalisation in Southeast Asia: a comparison of Indonesia, the Philippines, and Thailand," 2007.

[14] N. Kurniasih, "Internet Addiction, Lifestyle or Mental Disorder? A Phenomenological Study on Social Media Addiction in Indonesia," KnE Soc. Sci., vol. 2, no. 4, pp. 135-144, 2017.

[15] S. Sulartio, Masyarakat warga dan pergulatan demokrasi: menyambut 70 tahun Jakob Oetama. Penerbit Buku Kompas, 2001.

[16] D. Dhakidei, "Sistem Sebagai Totalisasi, Masyarakat Warga, dan Pergulatan Demokrasi.l dalam St. Sularto," Masy. warga dan pergulatan Demokr., pp. 3-29, 2001.

[17] R. E. Saputra, "Islam, Demokrasi, dan Institusi Politik di Indonesia, Turki, dan Dunia Islam,” Stud. Islam., vol. 24, no. 1, pp. 185-203, 2017.

[18] A. W. Prananta, "Gerakan Kesadaran Budaya Anti Korupsi, Intelektual Akademisi Dalam Perspektif Intellectual Craftsmanship C. Wright Mills," Ethn. Glob., p. 122, 2017.

[19] B. S. Hadiwinata, "BOURDIEU, NEOLIBERALISME, INTELEKTUAL DAN GERAKAN SOSIAL GLOBAL," MELINTAS, vol. 22, no. 1, pp. 471-485, 2006.

[20] B. Setiyono and R. H. McLeod, "Civil society organisations' contribution to the anti-corruption movement in Indonesia," Bull. Indones. Econ. Stud., vol. 46, no. 3, pp. 347-370, 2010.

[21] B. Widjojanto, "Koruptor itu Kafir, Telaah Fiqih Korupsi dalam Muhammadiyah dan Nahdatul Ulama (NU).” Jakarta: Mizan, 2010.

[22] B. Widjojanto, "Pengadilan Korupsi: Gagasan dan Implementasinya," J. Jentera, vol. 6, 2004.

[23] I. Saputra, "IMPLEMENTASI NILAI PANCASILA DALAM MENGATASI KORUPSI DI INDONESIA," JPPKn, vol. 2, no. 1, 2017.

[24] P. W. Kuncorowati, "Peranan penegak hukum di Indonesia dalam pemberantasan korupsi," J. Civ. Media Kaji. Kewarganegaraan, vol. 2 , no. 2,2015 .

[25] A. Supandi and D. M. Vernia, "PERAN PENDIDIKAN ANTI KORUPSI DALAM RANGKA MEWUJUDKAN PEMBANGUNAN NASIONAL YANG BERSIH DARI KORUPSI,” Res. Dev. J. Educ., vol. 1, no. 2, 2015. 
[26] D. K. Atmadja, "PERSPEKTIF HUKUM ISLAM TERHADAP PEMBUKTIAN TERBALIK PADA PERKARA TINDAK PIDANA KORUPSI." IAIN Raden Intan Lampung, 2017.

[27] W. B. Adisa, "The Middle Class and Political Transformation in Nigeria: An Appraisal of the Role of Asuu and Nba," Eur. Sci. Journal, ESJ, vol. 10, no. 28, 2014.

[28] M. A. S. Hikam, Islam, demokratisasi, dan pemberdayaan civil society. Erlangga, 2000

[29] Y. Nishikawa, Human security in southeast Asia. Routledge, 2010.

[30] N. Kurniasih et al., "Prototype Application Hate Speech Detection Website Using String Matching and Searching Algorithm," Int. J. Eng. Technol., vol. 7, no. 2.5, pp. 62-64, 2018.

[31] L. Abu-Lughod, ““ Orientalism' and Middle East Feminist Studies." JSTOR, 2001. 